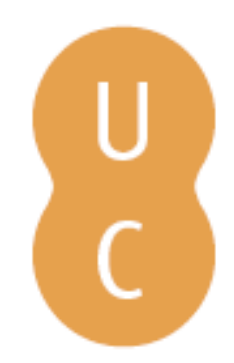

\title{
pommalina
}

\section{The challenges for youth coaches in youth sports}

Autor(es): $\quad$ Gonçalves, Carlos Eduardo; Figueiredo, António; Silva, Manuel Coelho e

Publicado por: Imprensa da Universidade de Coimbra

URL

persistente:

URI:http://hdl.handle.net/10316.2/31717

DOI:

DOI:http://dx.doi.org/10.14195/978-989-26-0506-7_14

Accessed : $\quad$ 26-Apr-2023 04:11:54

A navegação consulta e descarregamento dos títulos inseridos nas Bibliotecas Digitais UC Digitalis, UC Pombalina e UC Impactum, pressupõem a aceitação plena e sem reservas dos Termos e Condições de Uso destas Bibliotecas Digitais, disponíveis em https://digitalis.uc.pt/pt-pt/termos.

Conforme exposto nos referidos Termos e Condições de Uso, o descarregamento de títulos de acesso restrito requer uma licença válida de autorização devendo o utilizador aceder ao(s) documento(s) a partir de um endereço de IP da instituição detentora da supramencionada licença.

Ao utilizador é apenas permitido o descarregamento para uso pessoal, pelo que o emprego do(s) título(s) descarregado(s) para outro fim, designadamente comercial, carece de autorização do respetivo autor ou editor da obra.

Na medida em que todas as obras da UC Digitalis se encontram protegidas pelo Código do Direito de Autor e Direitos Conexos e demais legislação aplicável, toda a cópia, parcial ou total, deste documento, nos casos em que é legalmente admitida, deverá conter ou fazer-se acompanhar por este aviso. 
Manuel J. Coelho e Silva António J. Figueiredo Marije T. Elferink-Gemser Robert M. Malina Editors
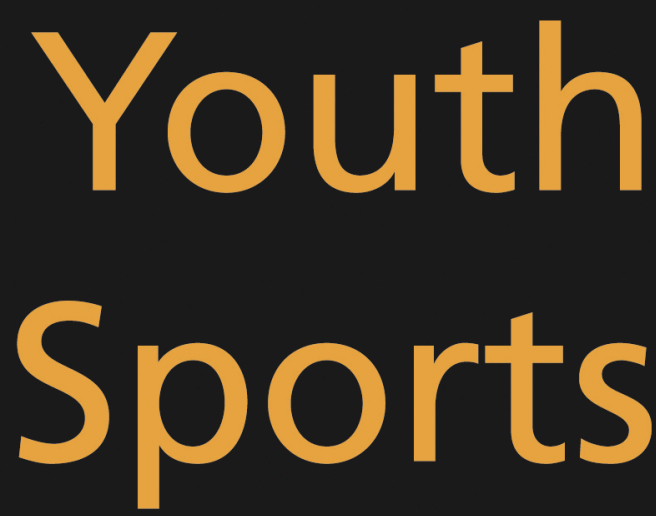

\section{Growth, Maturation and Talent}




\title{
EDIC̣̃̃o
}

Imprensa da Universidade de Coimbra

Email: imprensauc@ci.uc.pt

URL: http://www.uc.pt/imprensa_uc

Vendas online: http://www.livrariadaimprensa.com

\section{CONCEPÇÃO GRÁFICA}

António Barros

\section{EXECUÇÃO GRÁFICA}

\author{
Norprint
}

ISBN

978-989-26-0005-5

\section{DEPÓSITO LEGAL}


Manuel J. Coelho e Silva António J. Figueiredo Marije T. Elferink-Gemser

Robert M. Malina

Editors
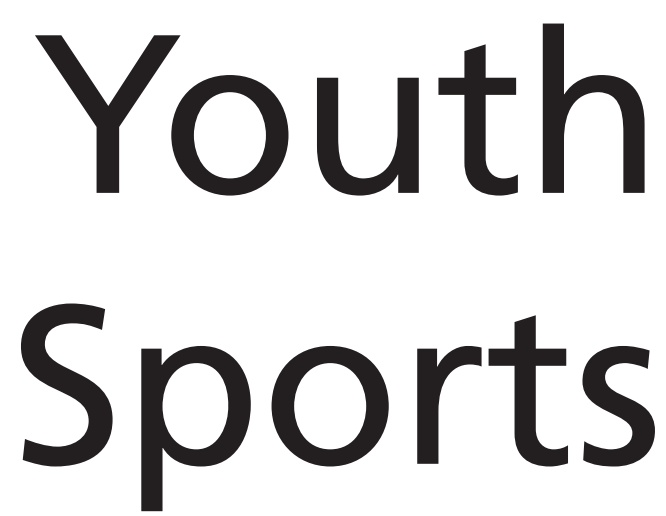

Growth, Maturation and Talent

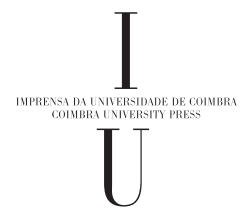


Part 3:

TRAINING 


\title{
CHAPTER I 4: THE CHALLENGES FOR YOUTH COACHES IN YOUTH SPORTS
}

\author{
Carlos Eduardo Gonçalves \\ António Figueiredo \\ Manuel Coelho e Silva
}

The importance of the coach in all aspects of sport practice has been unanimously highlighted and his activity frequently studied in the last few decades. Updates and adjustments to the theoretical approaches used are, however, a testimony to the conceptual and methodological difficulties raised at the academic level and the persisting uncertainties about the scope, content personal and professional qualities, learning pathways and professional status still associated with the practice of coaching.

Historically, in its pedagogical aspect, the study of human intervention in the context of interaction with other human beings has never been peaceful. The search for objectivity and rationality, necessary condition and fundament for a detachment that would allow a technological framework for the transmission of knowledge, was and still is a main concern of investigation. The progressive autonomy attained by disciplines comprised in sport science (biology, psychology, sociology, biomechanics) only stressed the issue furthermore, on account of bringing along into the sport system consolidated methods from their subjects of origin. The epistemological storm of the last decades left its marks on pedagogy and the "war of sciences" (Santos, 2005) keeps alight on a field that, only in appearance, shows up as secondary.

Here the concern with the public well-being is the guiding principle: the investigation is born from the desire for an objective usefulness (Tillion, 2009). In order to be able to discourse on the subject of the human sciences, erudition is, by itself, not enough, and the experience lived is the basic substrate on which the knowledge relative to our species is grounded: the events lived are key to the ones observed. With the so called exact sciences, when a researcher observes a phenomenon, it is possible to make the distinction between the observer, the instrument and the object. With the human sciences, observer, instrument and object are separated by vague boundaries and the experiments are customarily biased. There is a fundamental empathy between the observer and the observed, companion of the slow pace at which the knowledge is assimilated. A significative scientific efficiency can only be born from a rigourous alternation between action and 
research. More than the publishing of scientific articles, it is more important to perfect actions, sometimes minor, that lend themselves better to influence active communities.

Upon accepting that coaching children and youths is an act of education and that sport contributes to the development of the autonomous individual character, the study of the coach as a pedagogical agent is reinstated with interest, assuming the affirmative perspective of the search for a usefulness of the scientific knowledge (Schmidt-Millard, 2003). Whilst in high performance sport the specialization and focus on results and the existence of multi-disciplinary technical teams allow the coach to concentrate in the questions that favour performance, in the context of children and youth sport being a coach is beyond the mere organization and management of training sessions and competition supervision. Bronfenbrenner's (1999) bio-ecological model of development points out that the quality of interactions between the participants and the coach (among other subjects) is determinant for the success of the sportive experience conveying to the coach multiple and complex responsibilities.

Recent research in the topic has been focusing around three main areas: a) the contents of the coach's knowledge; b) the instruction and education of the coach; c) intervention upon the coach's practices.

Only recently has the theoretical and practical wealthiness of the accumulated research in the areas mentioned been recognised as "useful scientific knowledge", assuming a multi- and inter-disciplinary character and overflowing from the psychological and sociological research unto the pedagogical field where the development of children and youth coaching has always taken place. Despite the weight of practical results that truthfully influence the coaching practice, we support Harwood's (2008) statement that future research on the topic should be accompanied by the pursuit of a greater objectivity on the instruments measuring the behaviour of the coach.

The development of the coach cannot be seen as the mere accumulation of knowledge or empirical experience but rather, as a process of conceptual, cognitive and affective changes. The coach's route from noviciate to seniority is seldom continuous. Indeed, while analysing the way in which the best youth coaches face their role, Gilbert and Trudel (2004), point out the fact that many of them associate the content of their intervention with the competitive level attained, emphasizing the issues related to specific preparation according to the increase of their athletes specialization.

In face of the current knowledge imprecision and debility of the theoretical framework some authors (Jones, 2006; Mclaren, 2007), in pursuit 
of a post-structuralist re-conceptualisation and of modern critical thought, point out in recent literature the frailties of the coach's activity, when taken as a professional occupation, and clearly place it in the field of pedagogy demanding it to be theoretically located and analysed in that context. Although departing from a different point, Araújo (2009) argues that many intervention programs in sport pedagogy are based on "no theoretical framework" with consequences to the analysis and interpretation of the data. Furthermore, the same author blames the lack of correspondence between theory and practice.

The epistemological hazards when approaching the theme are important. First, due to the irreducibility of the individualism of the coach's activity, influenced by a sportive and living biography (Feltz, Hepler, Roman, \& Paiement, 2009; Ramos, Nascimento, \& Graça, 2009). Second, due to the wide ecological variability in which coaches, athletes, families and sport agents interact in different social, economical, geographical and organizational contexts. Third, due to the complexity of the tasks, never repetitive, because resulting from human relationships.

Against this background, any epistemological and theoretical approach anchored in the positivist paradigm wishing to quantify and generalize the research, lack a solid foundation. Although refusing the narrow and mystifying classification of post-modern, the challenge posed to positivism assumes the complexity of social life and the ever changing role of the several subjects in interaction, along with all their intentions, beliefs and hesitations. It is not a question of proving our theories and models exact, but instead a search to interpret reality, taking the circumstances, existing structures and the power of the human agency (Toulmin, 2003) into account. The scientific knowledge resulting from this human agency cannot be reduced to a value-free cognitive dimension, being as it is historically and ecologically immersed. Because these epistemological and ethical choices are the ones determining the research design and the methodological choices that legitimate the knowledge about the reality.

There seems to be a consensus among coaches in that they value more their own daily experiences as a source of learning than organized curricular instruction. Seemingly there is no reliable evidence on the effect of training programs on their behaviour and the responsibility of the competent teaching institutions ends with the issue of a certification. More than putting together a plan of formal education/training, the interactions between learners/athletes and professors/coaches, designated by Wikeley and Bullock (2006), are the more capable ones, the ones that make up the basis of the learning relationship and the ones that posses the potential to transform the 
involvement of children and youths in sport into positive experiences with lifelong impact.

However, edification through practice has for the coach the cost of always being individual and predominantly solitary. For the young coach this process can be a source of doubt, tension or even frustration. Because even if the several available coaching training curricula, from public or private responsibility, brought an effective dissemination of the scientific knowledge of training, notoriously raising the level of specific preparation of the coaches, these still perceive the daily practice as the best route to attain proficiency in pedagogy and communication, cornerstones of the quality of the relationship with the athletes (Harwood, 2008; Cassidy, Potrac \& McKenzie, 2006). In face of this problem, the potential contained in the concept of Coaches' Community of Practice seems to offer a good perspective of development (Culver \& Trudel, 2006).

The fact that many coaches seem to prefer to share experiences and knowledge with coaches outside their clubs or leagues is a severe limitation for cooperative work. However, recent interventional studies (Harwood, 2008; Culver \& Trudel, 2006) proved that the situation can be reversed if the coaches believe in the relevance of the benefits, participate in the decision process, and time is available to assess the changes in behavior. These studies also showed that the will to cooperate and to share their weaknesses in front of colleagues must come from inside the organization and rarely works with the help of outside specialists. The role of the head coach as a "more capable one "among equals is crucial in bringing together the other members of the coaching staff.

Thus, this initiation of the coach in the tradition and culture of his community can be fostered by a process of mentoring, led by a coach with a higher level of experience and expertise. Many coaches recognize that during their career they have gone through an informal but important process of mentoring. The problem is that this vital personal interaction results most of the time from hazardous circumstances. The inclusion of deliberate mentoring in a self-regulated Community of Practice should be able to provide the quality and stability required by the personal and professional growth of a young coach.

Because the really meaning of professional expertise cannot be reduced to a succession of years on the job. Coaching expertise is a construction of knowledge built through specific and social practice and learned through formal and informal sources (Gilbert \& Trudel 2004). Therefore, it seems that much of the young coach's new or restructured knowledge emerges from the context of practice where he/she interacts with 
athletes, families, other coaches, and the traditions and culture of the organization (Ramos, Nascimento \& Graça, 2009). It means that road to coaches' expertise is strongly contextualized and one the key factors for the success of this personal and social experience is given by the community of practice and the quality of the mentor(s).

The blend of formal coach education with the participation in a community of practice provides the young coach with important theoretical and practical tools to deal with the challenges of youth sport. However, the heavy influence of context demands a deep capacity of reflection about the conditions of daily practice and ecological environment. Only the reflective thinking allows the coach to transfer his/her experience to similar situations. Having in mind the conflict experienced by youth coaches between the search for victories and the well being of participants, only a reflective attitude about practice within a caring community of coaches enables the novice to transform

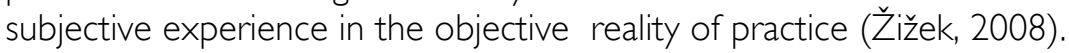

The study of the effects of the ecology of practice on coaches' learning and insertion in the sport culture at various levels is a promising field of research. The theoretical frameworks described by Araújo and Davis (2009) or Krebs (2009) provide interesting possibilities to understand how different organizations and different cultures are more favourable or detrimental to the personal or professional growth of young coaches.

The truth is that coaches exist and develop themselves in function of sport results. What is the meaning of those results is a major question that can be a factor of tension and conflict for youth coaches. The current shift in the social perspective on sport, in favour of an instrumental understanding of participation, viewed as a way to a more active and healthy lifestyle, is an additional pressure on the coaches. The contradiction between sport specific results, consequence of the normal sport activity, based on a typical training ethic, and the expectations of the youngsters and their families, leads to frustration, the coaches blaming the lack of enthusiasm and compromise of the new generations. The cooperative reflection within a positive community of coaches associated to expert mentoring, would certainly help the novices to act in a non-routine, changing environment.

This important problematic issue leads us again to the beginning of this chapter. Being a (youth) coach means to be a pedagogical agent in a very specific context. Coaches'education is a field of study where very little has been done to improve the quality of training and its assessment. If we agree that youth coaches education programs must include the integration in communities of practice with positive environments and that expert mentors play important roles in the professional growth of the novices, than sport 
organizations must deal with the topic in a serious manner. Until now, intervention studies, sometimes with excellent results, have been carried in episodic way. Longitudinal designs are needed to assess the effects of organized interventions, mentoring programs, and coaches' satisfaction and dropout. If coaches' quality is vital for youth sport, than efforts are needed to help young youth coaches to become experts to help young athletes to experience sport as a part of their personal development.

\section{REFERENCES}

Araújo D, \& Davids K (2009). Ecological approaches to cognition and action in sport and exercise: ask not only what you do, but where you do it. International Journal of Sport Psychology, 40, I, 38-49.

Benjamin W (2004). Imagens de pensamento. Lisboa, Assírio \& Alvim.

Bronfenbrenner $U$ (1999). Environments in developmental perspective: theoretical and operational models. In SL Friedman \& TD Wachs (Eds.), Measuring environment across the life span: Emerging methods and concepts (pp. 3-28). Washington, DC, American Psychological Association.

Cassidy T, Potrac P, \& McKenzie A (2006). Evaluating and reflecting upon a coach education initiative: The CoDe of Rugby. The Sport Psychologist, 20, |46-|6|.

Culver D, \& Trudel P (2006). Cultivating coaches' communities of practice. In $\mathrm{R}$ Jones (Ed.), The Sports Coach as Educator (pp. 97-II2). London, Routledge.

Feltz D, Hepler T, Roman N, \& Paiement C (2009). Coach efficacy and volunteer youth sport coaches. The Sport Psychologist, 23, I, 24-4I.

Fraser-Thomas J \& Côté J (2009). Understanding adolescents positive and negative developmental experiences in sport. The Sport Psychologist, 23, I, $3-23$.

Gilbert W, \& Trudel P (2004). Role of the coach: how model youth team sport coaches frame their roles. The Sport Psychologist, 18, 21-43.

Harwood C (2008). Developmental consulting in a professional football academy: the 5Cs Coaching Efficacy Program. The Sport Psychologist, 22, I09- 133.

Krebs R (2009). Bronfenbrenner's bioecological theory of human development and the process of development of sports talent. International Journal of Sport Psychology, 40, 108-135.

McLaren P (2007). Pedagogia crítica. Mangualde, PT, Edições Pedago.

Ramos V, Nascimento JV, \& Graça A (2009). Análise do processo de instrução no treino de jovens: um estudo de caso no basquetebol. Revista Portuguesa de Ciências do Desporto, 9, I, 52-63.

Schmidt-Millard T (2003). Perspectives of modern sports pedagogy. European Journal of Sport Science, 3, 3, I-7.

Tillion G (2009). Fragments de vie. Paris, Le Seuil. 
Toulmin S (2003). Como a razão perdeu o seu equilibrio. In BS Santos (Ed.), Conhecimento prudente para uma vida decente (pp. 253-272). Porto, Afrontamento.

Werthner P, \& Trudel P (2006). A new theoretical perspective for understanding how coaches learn to coach. The Sport Psychologist, 20, 198212.

Wikeley F, \& Bullock K (2006). Coaching as an educational relationship. In R Jones (Ed.), The Sports Coach as Educator (pp. 14-24). London, Routledge. Žižek S (2008). Violence - Six sideways reflections. New York, Picador. 
Série

Investigação

Imprensa da Universidade de Coimbra

Coimbra University Press

2010

- U r

C • 